\title{
New or Old Dimensions in Librarianship
}

BY LEO R. RIFT

A T THE Montreal Conference of ALA, Dr. Samuel Rothstein delivered a speech $^{1}$ in which he advocated both extensive and intensive bibliographic information service by reference librarians almost to the exclusion of the present form of service (i.e., reader's advisory service and instruction in the use of the library and bibliographic tools). For effective bibliographic information service, however, the user must be able to understand what the library can do for him and to formulate his problems accordingly. Therefore, there still will be need for instruction in the techniques of using some of the basic bibliographic tools and their contents. To the best of my knowledge this instruction, though advocated for a considerable time (an old dimension of reference service) is yet in the frontier stage.

Toward the end of his talk Dr. Rothstein made four specific suggestions. His first item stated that libraries could afford the cost of the proposed broad scale reference service, and his fourth item expressed the hope that a foundation would underwrite a pilot project to test it. We disagree in part, however, with items two and three which read: ${ }^{2}$

2. The reference services-and especially the information service-can get a large share of the existing library budget. I have no wish to start one more civil war in the ALA, but it may well be that we spend too much money on our technical processes and not enough on our public services. (By the way, I happen to be in charge of technical processes at my library).

3. There seems to be sound reason for

1. Samuel Rothstein," "Reference Service: The New Dimension in Librarianship," CRL, XXIII (1961), 11-18.

Ibid., 17.
Mr. Rift is Serial Librarian, Southern Illinois University Library.

hope that advances in library technology can produce savings which could be applied to the expansion of information services. Much of our cataloging, circulation, and acquisitions work can be mechanized, and, for that matter, we are promised machines for "information retrieval" too. In any case, the point is the same; the library is freed to concentrate on the really intellectual tasks in librarianship, and prominent among them the information service.

Item two emphasizes division and budgetary competition between technical and public services, favoring the latter. Item three cuts across the lines, explaining economies in both services through mechanization. But, though this mechanization covers practically all areas of the technical services field, it covers only certain aspects of the public services, according to Dr. Rothstein. This mechanization, then, frees the library and a larger slice of the budget for the intellectual tasks and especially the information service.

We find it difficult to accept this interpretation of the technical services, and it is our aim to demonstrate that there are as many "really intellectual tasks" in the technical services as in the public services which are closely interrelated. For this purpose, we shall divide the functions of both services into three general categories:

First, there are the managerial and policy functions which deal with the interpretation and application of the over- 
all policies established by the library administration. These functions are performed by all employees in proportion to their position on the administrative ladder.

Second, there are the bibliographiccentered functions which revolve around the identification and location of bibliographic items and their organization in the library. Through the use of bibliographic tools, we must identify and locate items so that we can select and use or acquire them and so that we can organize them into a systematic collection. These are the essential functions of librarianship, including reference, cataloging, and acquisition.

Third, there are the non-bibliographic functions which are auxiliary to the other two. The non-bibliographic functions are not necessarily inferior from an intellectual point of view, but they are of a more general nature and only the details of their application are peculiar to librarianship. They can be performed by people trained primarily in other fields who have acquired some knowledge of library techniques, and many of these tasks can be mechanized.

With reference to the bibliographiccentered functions, we wonder who is supposed to do the organizing and analyzing work. The reference librarian must look at the material from the particular point of view of the individual patron he serves. In order to do so, he must use tools provided by those who organize and analyze library materials from a more general or more objective point of view, because the tools must be valid for many reference situations. Who shall produce these tools but the librarians involved in technical processes? Not only do catalogs, bibliographies, and indexes form these basic reference tools, but the system of organization of his library also helps the reference librarian in his bibliographic search. In order to expand the reference service in the direction outlined by Dr. Rothstein, we must simul- taneously expand our activities of analyzing library materials. These activities belong as much in the field of librarainship as does the expanded reference service.

Machines have helped and will help increasingly in information storage and retrieval. But much of this work will continue to be carried out on a more pedestrian level in the future, especially when helping those who seek more general and less exhaustive information. One field which needs considerable improvement is the subject analysis of parts of books on a level more in line with that of periodicals. Regardless of the extent of mechanization, we need as much expansion of bibliographic work at the input end (cataloging and indexing) as we need at the output end (reference service). Further investigation will then demonstrate that the librarians working on the frontiers at either end will be performing similar tasks: at the one, analyzing the specific materials and integrating them into usable tools, and, at the other, retrieving from these tools the information for a specific purpose. If we still look at these tasks as belonging to separate technical and reference services, then we must concede that an increase in budgetary expenditure on the reference end must be met by an increase on the technical services end.

We may, however, resolve this dilemma by looking back to 1948, when Raynard Swank wrote, "It takes little imagination to see that the cataloger and the bibliographer perform an almost identical function, that of organizing books for use. ... The wonder is how, in our library organization, the two ever got separated in the first place." 3

In the now prevalent organizational pattern, the cataloger "well understands the need for correlating his work with that of bibliographers, but appears helpless to do much about it." 4 These

s Raynard G. Swank, "The Cataloging Department in the Library Organization," Library Quarterly. XVIII (1948), 28

4 Ibid., 29. 
thoughts were seconded by Louise Prevost: "A man or woman to be fit for a directorship of bibliographic control must be an out-and-out cataloger of first water with a touch of creative fire. Moreover, such men and women may turn out to be the salvation of essential librarianship. $^{5}$. . . Alex Ladenson's objection that public reference librarians are not bibliographers, however this may or may not apply in individual cases, begs Dr. Swank's conception entirely. Where that objection holds, there is all

5 Marie Louise Prevost, "A Head Cataloger Looks at Processing," Journal of Cataloging and Classification, V (1949), 34. the more reason to call catalogers to the rescue." 6

The answer to Dr. Rothstein's search for the new dimension may well be in a bibliographic information and research service sired, if you wish, by the present reference service, but conceived, nurtured, and weaned by catalogers. Such service deserves our wholehearted support. It symbolizes librarianship as a profession rather than as a technology.

- Ibid., 38. Swank advocated an organization of four departments: 1.) Acquisitions (Selection and ordering of materials); 2.) Bibliography (Organization including bibliographic service); 3.) Circulation (Control of physical orientation); 4.) Reference (Presumtrol of physical orientation); 4.) Reference (Presumably reader's advice and orientation). Ladenson advoarticle, "The Acquisition and Preparations Department," Library Quarterly, XVIII (1948), 200-205.

\section{Representatives of ALA}

ALA representatives at recent academic ceremonies were: Jack Dalton, dean of Columbia University School of Library Service, at the installation of Richard Franklin Humphreys as president of the Cooper Union, New York, on February 12; Robert A. Talmadge, director of Tulane University Library, New Orleans, at the inauguration of John Anderson Hunter as president of Louisiana State University, Baton Rouge, on April 7; Harold Lancour, associate director of the Graduate School of Library Science, University of Pittsburgh, at the inauguration of Paul Ausborn Miller as president of West Virginia University, Morgantown, on April 11; Miss Howard Hubbard of the ALA Washington Office at the opening of the Laubach Literacy Fund's new headquarters, Washington, D. C., on April 12; Roger Bristol, Alderman Library, University of Virginia, Charlottesville, at the inauguration of John A. Logan, Jr., as president of Hollins College, Virginia, on April 14; Helmer L. Webb, librarian of Union College, Schnectady, N. Y., at the inauguration of Edward John Sabol as president of the State University of New York, Cobbleskill, on April 19; Peter Spyers-Duran, ALA headquarters staff, Chicago, at the dedication of the Charles B. Phillips Library, Aurora College, Aurora, 11l., on May 19; Victor A. Schaefer, director of libraries, Notre Dame University, at the dedication of McMillen Library, Indiana Technical College, Fort Wayne, on May 19.

John F. Harvey, dean of the School of Library Science, Drexel Institute of Technology, Philadelphia, represented ACRL at the sixty-six th annual meeting of the American Academy of Political and Social Science in Philadelphia on April 13 and 14. 